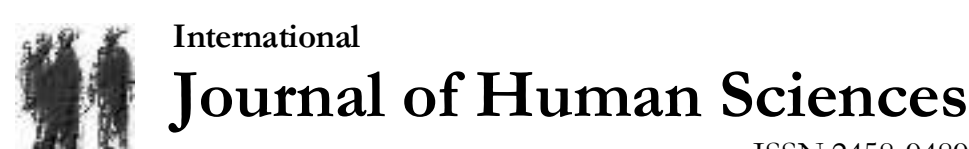 \\ ISSN:2458-9489
}

Volume 14 Issue 4 Year: 2017

\section{A new approach to Special Judo Fitness Test index: Relative index ${ }^{1}$}

\author{
Özkan Işık ${ }^{2}$ \\ İlkay Doğan ${ }^{3}$ \\ Halil İbrahim Cicioğlu ${ }^{4}$ \\ İrfan Yildirım ${ }^{5}$
}

\begin{abstract}
Although judo and wrestling have different rules, these branches are two different Olympic sports branches, partly based on similar basic techniques. For example; the technique called "Ippon-SeoiNage" (one shoulder throw) in judo is mechanically the same as the technique called "Arm Throw" in wrestling. The aim of this study was to gain relative special judo fitness test (SJFT) index with a new approach to the SJFT index used in the literature. The maximum number of "arm throw" is required from wrestlers during the tests. The test consists of 3 sets. The sets are $15 \mathrm{sec}, 30 \mathrm{sec}$, and $30 \mathrm{sec}$, respectively, and rest between the sets is 10 seconds. The heart rate of the wrestlers has recorded at the end of each set of the test and 1 minute after. The wrestlers were classified as the elite and sub-elite group and also as weight classification. Statistical analyses were performed using Mann-Whitney $U$ test and Kruskal Wallis test. There is no statistical difference between elite and sub-elite female wrestlers according to heart rate, the number of "arm throw", SJFT index, and relative SJFT index. On the other hand, there is a statistical difference in relative SJFT index according to weight classifications. Accordingly, lightweight wrestlers have highest relative SJFT index than the other groups. As a result of this study, there was no difference in the weight categories of the wrestlers according to the SJFT index, whereas there was a difference in the weight categories of the wrestlers according to the relative SJFT index. The use of the relative SJFT index to determine the difference between the weight categories will provide more accurate results for performance evaluation.
\end{abstract}

Keywords: Special judo fitness test; Wrestling; Performance; Arm throw; Ippon-Seoi-Nage

\section{Introduction}

In the last twenty years, athletes have become more powerful, and athletic performances have continued to improve in conjunction with improvements in exercise prescriptions. This has resulted in an increased interest in the measurement of anaerobic fitness (Karimi, 2016). For this reason, accurate anaerobic fitness assessment is very important for athletes. Nowadays, anaerobic fitness tests are applied in clinical and field settings. These tests assess an athlete's capability to

\footnotetext{
1 This study was presented as an oral presentation at World Congress of Sport Sciences Researches, 23-26 Dec 2017, Manisa-Turkey.

2 PhD., Afyon Kocatepe University, School of Physical Education and Sports, ozkanisik86@hotmail.com

${ }^{3} \mathrm{PhD}$. Afyon Kocatepe University, Faculty of Veterinary, Department of Biostatistics, ilkaydogan@aku.edu.tr

${ }^{4}$ Assoc. Prof., Gazi University, Faculty of Sport Sciences, cicioglu@gazi.edu.tr

${ }^{5}$ Assoc. Prof. Mersin University, School of Physical Education and Sports, iyildirim76@,hotmail.com
} 
Ișık, Ö., Doğan, İ., Cicioğlu, H. İ., \& Yıldırım, İ. (2017). A new approach to Special Judo Fitness Test index: Relative index. Journal of Human Sciences, 14(4), 4219-4225. doi:10.14687/jhs.v14i4.5100

produce power and speed in a short period of time or over a relatively short distance (Isik et al., 2014; Isik et al., 2015; Alpay, 2016; Sever et al., 2017).

Many different tests of physical fitness have been used in the evaluation of performance in combat sports athletes in all over the world. In some sports (judo and wrestling, etc.), special fitness tests have been used to evaluate athletic performance (Sterkowicz, 1995; Utter et al., 1997; Franchini et al., 2005; Eyuboğlu, Aslan, \& Koz, 2015). For example, in the judo, the special judo fitness test (SJFT) is commonly used to evaluate judo-specific performance (Franchini, Vecchio, \& Sterkowicz, 2009; Casals et al., 2016; Eyuboğlu \& Özkan, 2016; Garbouj et al., 2016). Although judo and wrestling have different rules, these branches are two different Olympic sports branches, partly based on similar basic techniques. For example; the technique called "lppon-seoi-nage" (one shoulder throw) in Judo is mechanically the same as the technique called "Arm Throw" in Wrestling. Due to this similarity, Karimi (2016) was tested the reliability of the special judo fitness test for wrestlers. Moreover, the average index values obtained by Karimi (2016) from wrestlers and the average index values obtained from judokas in the literature are almost similar (Drid et al., 2009; Jagiello, Beata, \& Walery, 2009). This result shows that the special judo fitness test can be accepted as criteria for evaluating the performance of the wrestlers.

Many studies have evaluated the performances of judokas using SJFT index results. In these studies, usually, they have assessed either on the same weight category athletes (Drid et al., 2015) or on studies including repeated measures of a sample (Franchini et al., 2015; Casals et al., 2017). Judo and wrestling are two sports with weight classification. For this reason, when comparing the performances of athletes in different weight categories, the relative SJFT index results should be used instead of the SJFT index results. Thus, performance changes of the athletes in the different weight categories are evaluated more accurately. Because the SJFT index values of athletes in different weight category may vary according to their physical characteristics. For this reason, the SJFT index values should be standardized as a value for per kilogram. For example; the SJFT index values of athletes in the two different weight categories are the same. In this case, when the athletes are compared, we can not say that they are equal. But, when relative SJFT index values per $\mathrm{kg}$ are calculated, we can compare these athletes. For this reason, standardizing the SJFT index values as a value for per $\mathrm{kg}$ will provide us to obtain more accurate results in comparing athletic performance between the athletes. In this context, the aim of this study was to gain relative index with a new approach to the SJFT index used in the literature.

\section{Material and Method \\ Participants}

The purposive sampling method was used in this study. A total of 18 senior female wrestlers from Turkish national team participated in the study. All wrestlers were divided two groups as an elite and sub-elite group in this research. In the elite group, consisted of 8 wrestlers, all competitors won at least 1 medal in the European Wrestling Championship, World Wrestling Championship or Olympic Games during the previous 3 years. The sub-elite group, consisted of other 10 wrestlers, won at least 1 medal but only in national competitions (Turkey). Moreover, wrestlers were divided into three groups according to their competition weight categories. The lightweight wrestlers were consisted 48, 53, and $55 \mathrm{~kg}$, the middleweight wrestlers were consisted 58, 60, and $63 \mathrm{~kg}$, and heavyweight wrestlers were consisted 69 and $75 \mathrm{~kg}$.

\section{Experimental approach}

All measurements were performed immediately after the full rest day in the senior female wrestling national team camp. The wrestlers have not participated SJFT before, therefore information about SJFT was given by the researchers and all wrestlers gave written informed consent to the researchers. Resting heart rates of the wrestlers were recorded and familiarization was applied for SJFT at a low heart rate. SJFT was performed for each wrestler after the heart rate drops to the resting heart rate level. 
Işık, Ö., Doğan, İ., Cicioğlu, H. İ., \& Yıldırım, İ. (2017). A new approach to Special Judo Fitness Test index: Relative index. Journal of Human Sciences, 14(4), 4219-4225. doi:10.14687/jhs.v14i4.5100

\section{Measurement of Body weight and height}

Body weight and height were measured using a Seca column scale (model 769, Seca Corporation, Hamburg, Germany) to the nearest $0.1 \mathrm{~kg}$.

\section{Special Judo Fitness Test}

SJFT was developed by Sterkowicz and reliability for SJFT was reported as 0.97 for judokas (Sterkowicz, 1995) and validity for wrestlers was reported as 0.867 (Karimi, 2016). Three wrestlers at similar body mass are needed to perform the SJFT. The SJFT is composed in three sets of 15, 30 , and $30 \mathrm{~s}$, with the 10 -s rest interval between each set. During tests, evaluated wrestler ( $3 \mathrm{~m}$ away from other wrestlers) throws two other wrestlers ( $6 \mathrm{~m}$ away from each other) as many times as possible using the arm throw technique that is similar to the Ippon-seoi-nage (one shoulder throw) technique in judo.

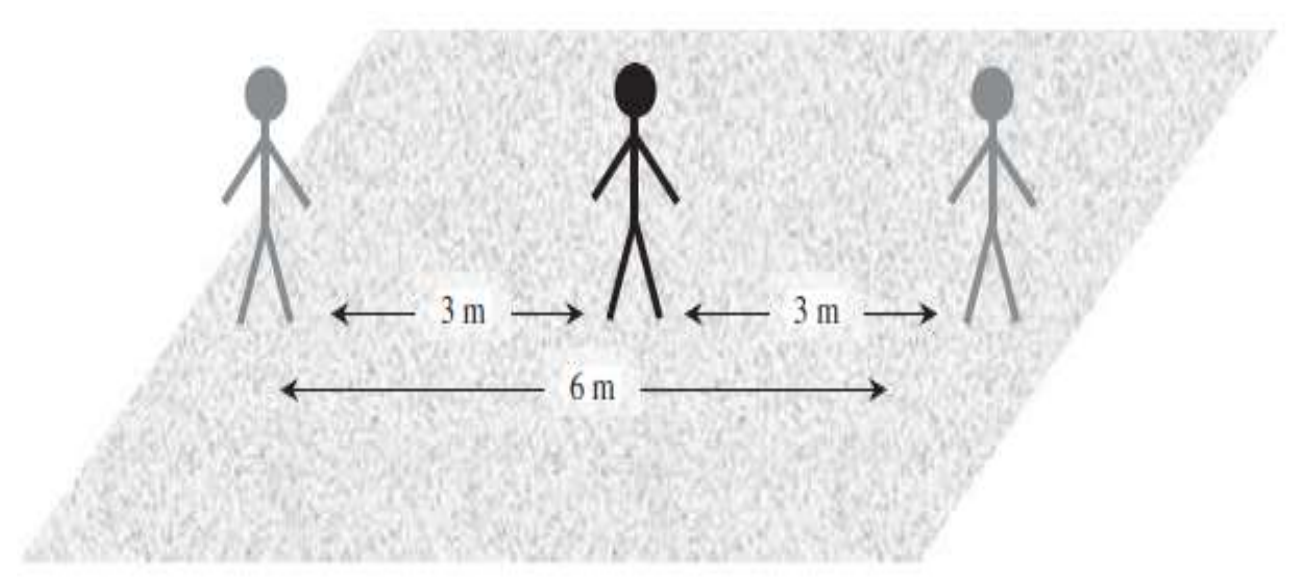

Figure 1. Representation of positions for wrestlers in SJFT (Karimi, 2016).

The total number of throws completed by the evaluated wrestler during each of the three sets was recorded; the evaluated wrestler's heart rate (HR) was measured immediately after and 1 min after the test (Polar Team², Polar, Finland). The SJFT index was calculated according to the following equation (Sterkowicz, 1995);

$$
\text { SJFT Index }=\frac{\text { Immediately after HR }\left(\mathrm{bpm} \cdot \mathrm{min}^{-1}\right)+\text { HR } 1 \mathrm{~min} \text { after }\left(\mathrm{bpm} \cdot \mathrm{min}^{-1}\right)}{\text { Total Throws }(\mathrm{N})}
$$

In many studies have used SJFT index values to evaluate performance (Franchini et al., 2015; Casals et al., 2017). Relative SJFT index value was calculated using the following equation:

$$
\text { Relative SJFT Index }=\frac{\text { SJFT Index }}{\text { Body Weight (kg) }}
$$

Sterkowicz (1995) have reported that a lower SJFT index indicates a better performance. Similarly, a lower relative SJFT index indicates a better performance for athletes. For example, the length of time that a heavyweight wrestler performs a technique as biomechanically and the running time to the other wrestler may be different from lightweight and/or middleweight wrestlers. For this reason, it is more accurate to use relative SJFT index values to compare the wrestlers in the different weight category. 
Issık, Ö., Doğan, İ., Cicioğlu, H. İ., \& Yıldırım, İ. (2017). A new approach to Special Judo Fitness Test index: Relative index. Journal of Human Sciences, 14(4), 4219-4225. doi:10.14687/jhs.v14i4.5100

\section{Statistical Analysis}

In the analysis of the data; mean and standard deviation values are given as the descriptive statistics. Moreover, Mann Whitney U test and Kruskal Wallis test applied for comparison of SJFT index variables according to classifications. Dunn's post hoc test was used for multiple comparison test after Kruskal Wallis test. The level of significance was set at $5 \%$.

\section{Results}

The mean age of the elite group $(n=8)$ was determined as $21.63 \pm 1.51$ years, height $165.38 \pm$ $5.40 \mathrm{~cm}$, and the body weight $60.09 \pm 6.65 \mathrm{~kg}$, whereas the mean age of the sub-elite group $(\mathrm{n}=10)$ was $21.30 \pm 1.95$ years, height $162.50 \pm 4.70 \mathrm{~cm}$, and the body weight $61.20 \pm 9.02 \mathrm{~kg}$.

Table 1: Descriptive Statistics of SJFT index variables of female wrestlers

\begin{tabular}{llc}
\hline Variables & $\mathbf{N}$ & Mean \pm Std. Deviation \\
\hline Throws set A (15 s) & 18 & $5.44 \pm 0.62$ \\
\hline Throws set B (30 s) & 18 & $9.22 \pm 1.06$ \\
\hline Throws set C (30 s) & 18 & $9.39 \pm 0.78$ \\
\hline Total throws & 18 & $24.06 \pm 2.10$ \\
\hline Heart rate after (bpm) & 18 & $181.33 \pm 8.37$ \\
\hline Heart rate 1 min after (bpm) & 18 & $107.00 \pm 9.71$ \\
\hline SJFT index & 18 & $12.08 \pm 1.29$ \\
Relative SJFT index & 18 & $0.21 \pm 0.03$ \\
\hline
\end{tabular}

Table 1 shows descriptive statistics of SJFT index variables. Total throws mean of female wrestlers is 24.06 \pm 2.10 ; SJFT index means of female wrestlers is $12.08 \pm 1.29$ and relative SJFT index means of female wrestlers is $0.21 \pm 0.03$.

Table 2: Comparison of SJFT index variables according to level of female wrestlers

\begin{tabular}{|c|c|c|c|c|c|}
\hline Variables & Level of Wrestlers & $\mathbf{N}$ & Median & $\bar{Z}$ & $\mathrm{p}$ \\
\hline \multirow{2}{*}{ Total throws } & Elite & 8 & 24.00 & \multirow{2}{*}{-0.764} & \multirow{2}{*}{0.445} \\
\hline & Sub-elite & 10 & 24.50 & & \\
\hline \multirow{2}{*}{$\begin{array}{l}\text { Heart rate after } \\
\text { bpm) }\end{array}$} & Elite & 8 & 177.00 & \multirow{2}{*}{-0.183} & \multirow{2}{*}{0.855} \\
\hline & Sub-elite & 10 & 180.00 & & \\
\hline \multirow{2}{*}{$\begin{array}{l}\text { Heart rate } 1 \text { min after } \\
(\mathrm{bpm})\end{array}$} & Elite & 8 & 111.00 & \multirow{2}{*}{-0.720} & \multirow{2}{*}{0.471} \\
\hline & Sub-elite & 10 & 108.00 & & \\
\hline \multirow{2}{*}{ SJFT index } & Elite & 8 & 12.41 & \multirow{2}{*}{-0.711} & \multirow{2}{*}{0.477} \\
\hline & Sub-elite & 10 & 11.42 & & \\
\hline \multirow{2}{*}{ Relative SJFT index } & Elite & 8 & 0.22 & \multirow{2}{*}{-1.510} & \multirow{2}{*}{0.131} \\
\hline & Sub-elite & 10 & 0.20 & & \\
\hline
\end{tabular}

Table 2 shows Mann-Whitney U test results. No statistical difference was found in any variables of the SJFT between elite and sub-elite female wrestlers ( $>>0.05)$. 
Issık, Ö., Doğan, İ., Cicioğlu, H. İ., \& Yıldırım, İ. (2017). A new approach to Special Judo Fitness Test index: Relative index. Journal of Human Sciences, 14(4), 4219-4225. doi:10.14687/jhs.v14i4.5100

Table 3: Comparison of SJFT index variables according to weight classification of female wrestlers

\begin{tabular}{|c|c|c|c|c|c|}
\hline Variables & $\begin{array}{l}\text { Weight Classification } \\
\text { of Wrestlers }\end{array}$ & $\mathbf{N}$ & Median & $\chi^{2}$ & $\mathrm{p}$ \\
\hline \multirow{3}{*}{ Total throws } & Heavyweight & 6 & 23.50 & \multirow{3}{*}{5.562} & \multirow{3}{*}{0.062} \\
\hline & Middleweight & 6 & 26.00 & & \\
\hline & Lightweight & 6 & 23.00 & & \\
\hline \multirow{3}{*}{$\begin{array}{l}\text { Heart rate after } \\
(\mathrm{bpm})\end{array}$} & Heavyweight & 6 & 186.00 & \multirow{3}{*}{5.988} & \multirow{3}{*}{0.051} \\
\hline & Middleweight & 6 & 180.00 & & \\
\hline & Lightweight & 6 & 174.00 & & \\
\hline \multirow{3}{*}{$\begin{array}{l}\text { Heart rate } 1 \mathrm{~min} \text { after } \\
(\mathrm{bpm})\end{array}$} & Heavyweight & 6 & 111.00 & \multirow{3}{*}{1.323} & \multirow{3}{*}{0.516} \\
\hline & Middleweight & 6 & 108.00 & & \\
\hline & Lightweight & 6 & 108.00 & & \\
\hline \multirow{3}{*}{ SJFT index } & Heavyweight & 6 & 12.89 & \multirow{3}{*}{5.158} & \multirow{3}{*}{0.076} \\
\hline & Middleweight & 6 & 11.20 & & \\
\hline & Lightweight & 6 & 12.41 & & \\
\hline \multirow{3}{*}{ Relative SJFT index } & Heavyweight & 6 & $0.19^{\mathrm{a}}$ & \multirow{3}{*}{12.316} & \multirow{3}{*}{0.002} \\
\hline & Middleweight & 6 & $0.20^{\mathrm{a}}$ & & \\
\hline & Lightweight & 6 & $0.23^{\mathrm{b}}$ & & \\
\hline
\end{tabular}

a,b: different letters show the difference between groups.

Table 3 shows Kruskal Wallis test results. No statistical difference was found in total throws, heart rate after (bpm), heart rate $1 \mathrm{~min}$ after (bpm) and SJFT index variables according to weight classification of female wrestlers $(\mathrm{p}>0.05)$. On the other hand, a statistical difference was found in relative SJFT index according to weight classification of female wrestlers $(\mathrm{p}<0.05)$. Accordingly, lightweight wrestlers have highest relative SJFT index median than the other groups.

\section{Discussion}

The SJFT index is often used to evaluate judo-specific performance in all over the world. However, there are many variables that need to be considered when assessing judo-specific performance. Casals et al. (2017) have reported that body mass and gender are significantly associated with the SJFT index. This information should be taken into consideration when evaluating athletes of different weight categories because heavyweight judokas obtain worse SJFT results than lightweight judokas, although there is not a classificatory adjustment by weight. Additionally, it has been reported that lightweight judokas have higher throwing speed (ippon-seoinage technique), more power and better oxygen uptake than heavyweight judokas (Almansba et al., 2010; Franchini et al., 2011). For this reasons, Casals et al. (2017) have reported that the judo athlete's body mass should be considered before applying the SJFT results at an elite level.

Numerous studies have evaluated relative output results instead of absolute outputs for talent identification and/or selection (Sánchez-Puccini et al., 2014; Isik et al., 2015). Because the use of relative outputs plays a more important role in determining individual differences. For example, it may think of it like the evaluation of Wingate anaerobic test performance results. A heavy person may have achieved higher absolute power outputs than lighter. However, this situation may result in opposite as the relative power output. In this context, the primary purpose of the study was to gain relative SJFT index value with a new approach to the SJFT used in the literature. The secondary purpose of the research was to compare senior female wrestlers according to their levels and weight classification. 
Işık, Ö., Doğan, İ., Cicioğlu, H. İ., \& Yıldırım, İ. (2017). A new approach to Special Judo Fitness Test index: Relative index. Journal of Human Sciences, 14(4), 4219-4225. doi:10.14687/jhs.v14i4.5100

In the current study, the total number of throws of female senior wrestlers $(n=18)$ was determined as $24.06 \pm 2.10$, heart rate immediately after SJFT 181.33 \pm 8.37 , heart rate 1 minute after SJFT 107.00 \pm 9.71 , SJFT index values $12.08 \pm 1.29$, and relative SJFT index $0.21 \pm 0.03$. Heart rates and total throws of female senior wrestlers are similar to many studies in the literature (Wolska et al., 2009; Smulski et al., 2011).

Many studies have reported that there is a difference between SJFT variables between female elite and sub-elite judokas (Franchini et al., 2005; Drid et al., 2008). For example, Franchini et al. (2005) have reported that there was a difference between elite and sub-elite female judokas' total throws and SJFT index results. In the study of Drid et al. (2008) was obtained similar results to Franchini et al. (2005). However, in the current study, there was no statistically significant difference any SJFT index variables according to the levels of female wrestlers. This result can be attributed to the fact that all athletes are in the national team and may have the level to represent the national team.

In the present study, it was determined that there was no significant difference when the SJFT index variables were compared according to the weight classification of senior female wrestlers. Despite that, Casal et al. (2017) have reported that lightweight athletes will have a better SJFT index results than heavyweight athletes. In addition, it was determined that there is a difference between the relative SJFT index obtained by a new approach. According to these results, it was determined that the lightweight wrestlers was a worse relative SJFT index than the middleweight and heavyweight senior female wrestlers. So, lightweight athletes need to be faster than middleweight and heavyweight.

\section{Conclusion}

The relative SJFT index can be used instead of the SJFT index for comparison of athletes in the different weight category. Because there are athletes in different weight category in a sports club or in the national team. As has been previously mentioned, the judo athlete's body mass and/or gender should be considered before applying the SJFT results at an elite level. For this reasons, the use of the relative SJFT index is recommended to compare individual developments of athletes with each other. Moreover, the relative SJFT index can be used as a criterion for talent identification and/or selection of basic educated judokas and wrestlers. Also, more accurate results can be obtained when comparing the athletes in the different weight category.

\section{References}

Almansba, R., Sterkowicz, S., Belkacem, R., Sterkowicz-Przybycien, K., \& Mahdad, D. (2010). Anthropometrical and physiological profiles of the Algerian Olympic judoists. Arch Budo, 6(4), 185-93.

Alpay, C. B. (2016). Comparison of Athletic Performances of Male Soccer Players with Respect to Their Respective Positions in Game. Anthropologist, 24(2), 519-525.

Casals, C., Escobar-Molina, R., Barranco-Ruiz, Y., \& Huertas, J. R. (2016). Special judo fitness test level and anthropometric profile of elite female cadet judokas. Revista de Artes Marciales Asiáticas, 11(2s), 40-41.

Casals, C., Huertas, J. R., Franchini, E., Sterkowicz-Przybycien, K., Sterkowicz, S., GutiérrezGarcía, C., \& Escobar-Molina, R. (2017). Special judo fitness test level and anthropometric profile of elite spanish judo athletes. The Journal of Strength \& Conditioning Research, 31(5), 12291235.

Drid, P., Trivic, T., \& Obadov, S. Fizicka pripremljenost dzudistkinja Srbije rocenjena primenom specificnog fitnes judo testa [Physical fitness in Serbian female judoists in specific judo test]. Homo Sporticus 10: 6-9, 2008.

Drid, P., Casals, C., Mekic, A., Radjo, I., Stojanovic, M., \& Ostojic, S. M. (2015). Fitness and anthropometric profiles of international vs. national judo medalists in half-heavyweight category. The Journal of Strength \& Conditioning Research, 29(8), 2115-2121. 
Işık, Ö., Doğan, İ., Cicioğlu, H. İ., \& Yıldırım, İ. (2017). A new approach to Special Judo Fitness Test index: Relative index. Journal of Human Sciences, 14(4), 4219-4225. doi:10.14687/jhs.v14i4.5100

Drid, P., Maksimovic, N., Matic, R., Obradovic, B., Milosevic, Z., \& Ostojic, S. M. (2009). Fitness profiles of elite female judokas of the Serbian national team. Medicina dello Sport, 62(3), 251263.

Eyuboğlu, E., \& Özkan, A. (2016). Relationships between special judo fitness test (sjft), flexibility and some variables of lower-upper body on young judokas. Applicable Research in Judo, 76-77.

Eyuboğlu, E., Aslan C. S., \& Koz, M. (2015). Özel Judo Uygunluk Testi (SJFT)'nin judo antrenmanları için egzersiz modeli olarak kullanılması, 6. Antrenman Bilimi Kongresi, Accessed on: http://www.sporbilimleri.hacettepe.edu.tr/abk2015/abk2015_v4.pdf

Franchini, E., Del Vecchio, F. B., Julio, U. F., Matheus, L., \& Candau, R. (2015). Specificity of performance adaptations to a periodized judo training program. Revista Andaluza de Medicina del Deporte, 8(2), 67-72.

Franchini, E., Del Vecchio, F. B., Matsushigue, K. A., \& Artioli, G. G. (2011). Physiological profiles of elite judo athletes. Sports Medicine, 41(2), 147-166.

Franchini, E., Takito, M. Y., Kiss, M. A. P. D. M., \& Strerkowicz, S. (2005). Physical fitness and anthropometrical differences between elite and non-elite judo players. Biology of Sport, 22(4), 315.

Franchini, E., Vecchio, F. B. D., \& Sterkowicz, S. (2009). A special judo fitness test classificatory table. Archives of budo, 5, 127-129.

Garbouj, H., Selmi, M. A., Sassi, R. H., Yahmed, M. H., Chamari, K., \& Chaouachi, A. (2016). Do maximal aerobic power and blood lactate concentration affect Specific Judo Fitness Test performance in female judo athletes?. Biology of sport, 33(4), 367.

Isik O, Alpay CB, Hazar S, Eker, H. (2014). A study examining the effects of changed rules of wrestling competitions on the muscular damage levels of the elite wrestlers. Turkish Journal of Sport and Exercise, 16(1), 18-24.

Isik, O., Ersoz, Y., Pazan, M., \& Ocak, Y. (2015). The effect of motivational music on wingate anaerobic test performance. Journal of Human Sciences, 12(2), 513-520.

Jagiello, W., Beata, W., \& Walery, S. (2009). Physical preparation of female judo competitors at selected stages of long-standing sports training. Archives of Budo, 5, 47-53.

Karimi, M. (2016). Validity of Special Judo Fitness Test in Iranian Male Wrestlers. International Journal of Wrestling Science, 6(1), 34-38.

Sánchez-Puccini, M. B., Argothy-Bucheli, R. E., Meneses-Echávez, J. F., López-Albán, C. A., \& Ramírez-Vélez, R. (2014). Anthropometric and physical fitness characterization of male elite karate athletes. International Journal of Morphology, 32(3), 1026-31.

Sever, O., Gönülateş, S., Bayrakdar, A., Demirhan, B., Geri, S., \& Zorba, E. (2017). Anaerobic Capacity Changes of the National Freestyle Wrestlers during the Olympic Qualification Competition Period. Journal of Education and Training Studies, 5(8), 26-29.

Smulski, W., Wolska, B., Jagiełł, W., \& Sawczyn, S. (2011). The correlation of general and sportspecific preparation indices of elite female judo competitors with their age-somatic characteristics. Arch Budo, 7(4), 233-238.

Sterkowicz, S. (1995). Test specjalnej sprawnosci ruchowej w judo. Antropomotoryka, 12, 29-44.

Utter, A., Goss, F., DaSilva, S., Kang, J., Suminski, R., Borsa, P., ... \& Metz, K. (1997). Development of a Wrestling-Specific Performance Test. The Journal of Strength \& Conditioning Research, 11(2), 88-91.

Wolska, B., Smulskij, V., \& Jagiello, W. (2009). The level of aerobic and anaerobic capacity and results of a Special mobility Fitness Test of female judo contestants. Baltic Journal of Health and Physical Activity, 1(2), 105-110. 